\title{
A mechanistic approach to anti-nociceptive potential of Artemisia macrocephala Jacquem
}

\author{
Mohammad Shoaib ${ }^{1}$, Ismail Shah" ${ }^{1 *}$ Niaz Ali ${ }^{2}$ and Wadood Ali Shah ${ }^{1}$
}

\begin{abstract}
Background: Artemisia macrocephala Jacquem (A. macrocephala), locally known as "Tarkha", is a perennial plant found abundantly in northern areas of Pakistan. It is widely used in traditional medicine to treat fever, pain, gastrointestinal disorders and diabetes. Till date, no published studies are available regarding the in-vivo antinociceptive potential of the crude extract and sub-fractions from the aerial parts of A. macrocephala.

Methods: Antinociceptive effects of the crude methanolic extract and its sub-fractions were assessed using experimental pain models, including chemical nociception induced by intraperitoneal acetic acid or subplantar formalin injection and thermal nociception like tail immersion test in-vivo.

Results: The administration of various doses of crude extract and its fractions showed a dose-dependent indomethacin like antinociceptive effect in acetic acid induced writhing, subplantar formalin injection animal model suggesting the involvement of central mechanism of pain inhibition. Moreover, the crude extract and sub-fractions, on tail flick model (thermal nociception) demonstrated the involvement of central mechanism and significantly increased the latency time to $66.54,82.94$ and $70.53 \%$. The antagonistic study proposed the possible involvement of opioid receptor using naloxone as non-selective antagonist. The pharmacologically active chloroform and ethyl acetate fractions were further subjected to column chromatography that lead to the isolation four compounds. These isolated compounds were then subjected to various spectroscopic techniques upon which they were confirmed to be one sterol and three flavonoid derivatives. These findings suggest that Artemisia macrocephala possesses peripheral and central analgesic potentials partially associated with opioid system that support its folkloric use for the management of pain. The isolated compounds are currently under investigation in our laboratory for analgesic activity and its possible mechanism of action.
\end{abstract}

Conclusion: The results in this study provide evidences that A. macrocrphala has anticonciceptive effects and can be used for treatment of pain in traditional therapies. This study opens a new channel for isolation of analgesic compounds from the specie that is used traditionally for the management of pain.

Keywords: Artemisia macrocephala, Acute toxicity, Antinociceptive activity, Formalin, Acetic acid, Tail immersion

\footnotetext{
* Correspondence: ismailshah09@yahoo.com; ismailshah09@gmail.com ${ }^{1}$ Department of Pharmacy, University of Malakand, Chakdara Dir Lower, Khyber Pakhtunkhwa (KPK), Pakistan

Full list of author information is available at the end of the article
} 


\section{Background}

Despite of the present scientific advancement in pain therapies, potent, safe and effective drugs are still needed for many painful conditions [1]. The current available therapies for pain, mostly elicit severe adverse effects $[2,3]$. Therefore, drugs with no such effects are searched throughout the world [4]. Natural products like plants, animals, microbes and marine life have contributed to almost $50 \%$ of current drugs that are used as a significant tool for the management of various ailments [5]. Searches from the past have led to the discovery of active analgesic from plants in shape of aspirin and morphine [6, 7].

The genus Artemisia has diverse uses in traditional system of medicine. Its members are used for abdominal pains and colds in the head, as expectorant for bronchitis and asthma, as poultice for rheumatoid arthritis, and as a plaster cast for broken bones [8]. Scientifically, many of its plants had been reported to possess antiinflammatory, insecticidal, analgesic, antispasmodic, antifungal, antibacterial and photo protective [9], while some of its species are used during labor pain [10]. On scientific basis, Artemisia herba alba had been proved to have clear antinociceptive and anti-inflammatory effects [11], Artemisia copa presents antinociceptive and topical anti-inflammatory [12], Artemisia absinthium possesses topical analgesic [13] and Artemisia dracunculus has significant analgesic and anti-inflammatory effects [14]. Different classes of chemicals, e.g., coumarins, terpenes, sesquiterpenes, flavonoids, aromatics, dipeptides, phenolics, coumarins, esterols, germacranolides, guaianolides, secoguaianolides and polysaccharides have been isolated from Artemisia species [15]. These constituents impart a wide-range of pharmacological effects like analgesic [16-19] antitumoral, antioxidant, anti-inflammatory [17-19] anti-cancer and immunomodulatory action [20-23]. Some species of this genus are used in beverages and in infusions for their digestive properties, serves as a base for some bitter drinks while its oils possess trypanocydal and mosquito repellent properties [24]. A. macrocephala Jacquem is an important member of this genus which is found abundantly in Northern Areas of Pakistan [25]. The preliminary phytochemical investigations confirmed the presence of terpenes, flavonoids, saponins and alkaloids [26]. Our previous work on this specie revealed its traditional use for the management of gut spasms and confirmed its antispasmodic response using in vitro rabbits' jejunal preparations. Apart from that, it also possesses antioxidant activity [25]. In another study, our group worked on its enzyme inhabiting potentials and confirmed that its essential oil obtained by process of hydro distillation has significant enzyme inhibition activity against acetylcholinesterase and butyrylcholinesterase activity that may be a possible alternative for treating Alzheimer's disease [27]. Apart from other folkloric uses, this specie is known for its anti-inflammatory and analgesic response; therefore, the present study was designed to explore on scientific basis the traditional use of A.macrocephala for possible antinociceptive potential using animal model. The finding of this study may further lead to the investigation for the isolation and structure elucidation of bioactive compounds responsible for its anti-inflammatory and analgesic activities.

\section{Methods \\ Collection and authentication of plant materials}

Fresh aerial parts of $A$. macrocephala were collected in August, 2014 from the nearby hills of Badwan Chowk, Dir Lower, Khyber Pakhtunkhwa, Pakistan. The species was identified by plant taxonomist, Dr. Nasur Ullah, Assistant Professor University of Malakand Chakdara Dir Lower Khyber Pakhtunkhwa, Pakistan. A voucher specimen "Am-01-2014" was submitted to the herbarium of Department of Botany, University of Malakand.

\section{Extraction}

The plant material was kept in shade at room temperature for drying. It was afterwards crushed and pulverized by a mechanical grinder to obtain fine powder. The fine powder $(5.5 \mathrm{~kg})$ was then macerated in commercial grade methanol with occasional shaking for 22 days at room temperature. The materials were then filtered off. The process was repeated 3 times. The filtrates were combined and evaporated under reduced pressure, using a rotary evaporator, until a dark greenish color crudemethanolic extract (Am.Cme) was obtained.

\section{Fractionation}

The crude Am.Cme. (500 g, 9.09 \%) was suspended in distilled water $(400 \mathrm{~mL})$, which was successively fractionated with $400 \mathrm{~mL}$ of $n$-hexane. The process was repeated until complete fractionation. Similar procedure was followed for fractionation with chloroform and ethyl acetate till it successively gave $44 \mathrm{~g}$ of $n$-hexane fraction (Am.n-hex, $8.8 \%$ ), $77 \mathrm{~g}$ of chloroform fraction (Am.Chf, 15.4\%), 40.4 $\mathrm{g}$ of ethyl acetate (Am.EtOAc, $8.08 \%$ ) and $32 \mathrm{~g}$ of residual aqueous fraction (Am.Aq, $6.4 \%$ ). The fractions were refrigerated till pharmacological screenings.

\section{Preliminary phytochemical screening and isolation of compounds}

Based upon our previous findings of various phytochemicals in the crude extract [25], the subsequent fractions were subjected to preliminary phytochemical screening to explore the natural product rich fraction. Further, the pharmacologically active fractions (chloroform and ethyl acetate) were subjected to column chromatography for 
isolation of active chemical constituents that were further subjected to various spectroscopic techniques like mass, $1 \mathrm{H}-\mathrm{NMR}$, NOESY, COSY, HMBC and HSQC for structure elucidation.

\section{Animals and ethical approval}

Animals used, were Swiss albino mice of either sex. They were obtained from animal house of Department of Pharmacy, University of Malakand, Chakdara, Dir Lower, KPK, Pakistan. They were maintained under standard conditions of laboratory and were fed standard food and water ad libitum. All the protocols of the experiment were approved by ethical committee of Department of Pharmacy (No: E-AM-01-2009), University of Malakand as per Bye Laws 2008 of the University of Malakand (Scientific Procedures Issue-I).

\section{Acute toxicity}

The crude methanolic extract and fractions were tested for acute toxicity study as per standard protocol [28]. Swiss albino mice were administered 500, 1000, 1500 and $2000 \mathrm{mg} / \mathrm{kg}$ of the crude extract and fractions per oral route. One group received normal saline that served as negative control. The animals were observed for $6 \mathrm{~h}$ continuously for changes in their behavior. Mortality for the next 14 days was also noted.

\section{Analgesic activity \\ Acetic acid induced writhing test}

The peripheral antinociceptive response is determined through acetic acid induced writhing test.

Two groups of mice $(n=6)$ for each sample were prepared. They were given 150 and $300 \mathrm{mg} / \mathrm{kg}$ of crude extract and 100 and $200 \mathrm{mg} / \mathrm{kg}$ (orally) of sub-fractions $1 \mathrm{~h}$ before the injection of $10 \mathrm{~mL} / \mathrm{kg}$ of $1 \%$ acetic acid intraperitoneally. Negative control group was given $10 \mathrm{~mL} / \mathrm{kg}$ of $1 \%$ solution of Tween 80 (1\%, v/v) while positive control group was given $50 \mathrm{mg} / \mathrm{kg}$ of diclofenac sodium intraperitoneally to overnight fasting mice. Writhing and stretching number was noted and percent protection was determined from the data [29].

\section{Formalin test}

This test was carried out as per Pandurangan et al. [30] protocol with a bit modification. Five mice per group were given different doses (150 and $300 \mathrm{mg} / \mathrm{kg}$ crude and 100 and $200 \mathrm{mg} / \mathrm{kg}$ sub-fraction) of test samples. After $30 \mathrm{~min}$ of administration of test samples, $2.5 \%$ formalin $(20 \mu \mathrm{l})$ was injected subcutaneously (s.c) in mice' hind paw. The time spent in licking of the test paw (to which test samples were injected) in early phase (0-5 min) and late phase (15-30 $\mathrm{min})$ were recorded. Naloxone, opioid antagonist (2 $\mathrm{mg} / \mathrm{kg}$, s.c), standard drug indomethacin $(10 \mathrm{mg} / \mathrm{kg})$ and Tween $80(2 \%, \mathrm{v} / \mathrm{v})$ were also used.

\section{Tail immersion test}

In order to determine the central antinociceptive response of the test samples, the animals were given different doses (150 and $300 \mathrm{mg} / \mathrm{kg}$ crude and 100 and $200 \mathrm{mg} / \mathrm{kg}$ subfraction) of the sample intraperitoneally, $2 \%$ vehicle and $50 \mathrm{mg} / \mathrm{kg}$ of diclofenac sodium, $30 \mathrm{~min}$ prior to the immersion of the tail $(3 \mathrm{~cm})$ into hot water $\left(55 \pm 0.5^{\circ} \mathrm{C}\right)$. To assess the possible involvement of opioid receptors, morphine (agonist) in a dose of $5.0 \mathrm{mg}$ and naloxone (antagonist) in a dose of $2.0 \mathrm{mg}$ were used. The time of reaction taken at 15, 30, 45, 60, 75 and 90 min after administration of test samples were noted using a stopwatch [31].

\section{Statistical analysis}

Data are presented as mean $\pm \operatorname{SEM}(n=6)$. Graph Pad Prism was used for analysis of data followed by Dunnett's test for statistical significance using $p \leq 0.05$.

\section{Results}

Results for the preliminary phytochemical screening reveal the presence of flavonoids and saponins in the chloroform fraction and sterol and flavonoid in the ethyl acetate fraction. The chloroform fraction was found to be rich with flavonoids. Apart from flavonoids, saponins and terpenes were also present but in mild quantity. The pharmacologically active fractions (chloroform and ethyl acetate) lead to the isolation of four compounds. The integration of the isolated compounds Ism-1 to Ism-4 are summarized as under, while the original spectra are given in Additional file 1.

\section{Ism-1}

Pale yellow amorphous powder, IR $\left(\mathrm{KBr}, \mathrm{Cm}^{-1}\right)$, 3391, 3263, 1659, 1519. UV $\lambda_{\mathrm{MeOH}} \max \mathrm{nm}: 342$ and 347; ${ }^{1} \mathrm{H}-$ NMR (500 MHz, CD $3 \mathrm{OD}): \delta 7.59\left(\mathrm{~d}, 1 \mathrm{H}, J_{6^{\prime}, 5^{\prime}}=8.0 \mathrm{~Hz}\right.$, H-6'), 7.10 (br s, $1 \mathrm{H}, \mathrm{H}-2^{\prime}$ ), 7.09 (d, $1 \mathrm{H}, J_{5^{\prime}, 6^{\prime}}=8.0 \mathrm{~Hz}$, H-5'), 6.63 (s, 1H, H-2), 6.52 (s, 1H, H-8), 3.92 (s, 3H, $\mathrm{H}-4{ }^{\prime} / \mathrm{OCH}_{3}$ ), 3.90 (s, 3H, H-3' $/ \mathrm{OCH}_{3}$ ), 3.86 (s, 3H, H-6/ $\left.\mathrm{OCH}_{3}\right), \delta$ EI-MS: $m / z$ 344 $\left(\mathrm{M}^{+}\right), 329,326,301$ [32].

\section{Ism-2}

Light yellow amorphous powder, 1H-NMR $(500 \mathrm{MHz}$, acetone- $\left.d_{6}\right) \delta 12.98(\mathrm{~s}, 1 \mathrm{H}, \mathrm{H}-5 / \mathrm{OH}), 7.96\left(\mathrm{~d}, 2 \mathrm{H}, J_{2^{\prime}, 3^{\prime} /}\right.$ $\left.6^{\prime}, 5^{\prime}=8.0 \mathrm{~Hz}, \mathrm{H}-2 / \mathrm{H}-6\right), 7.03\left(\mathrm{~d}, 2 \mathrm{H}, J_{3^{\prime}, 2^{\prime} / 5^{\prime}, 6^{\prime}}=8.0 \mathrm{~Hz}\right.$, $\mathrm{H}-3 / \mathrm{H}-5), 6.68$ (s, $1 \mathrm{H}, \mathrm{H}-3), 6.66\left(\mathrm{~d}, 1 \mathrm{H}, J_{8,6}=2.0 \mathrm{~Hz}, \mathrm{H}-\right.$ 8), $6.32\left(\mathrm{~d}, 1 \mathrm{H}, J_{6,8}=2.0 \mathrm{~Hz}, \mathrm{H}-6\right), 3.92\left(\mathrm{~s}, 3 \mathrm{H}, \mathrm{H}-4^{\prime}\right.$ / $\left.\mathrm{OCH}_{3}\right)$. EI MS $m / z$ (\%) $284\left(\mathrm{M}^{+}\right), 255$ [33].

\section{Ism-3}

Slight yellow powder, IR $\left(\mathrm{KBr}, \mathrm{Cm}^{-1}\right), 3500,1662,1614$, 1512. UV $\left(\mathrm{AlCl}_{3}+\mathrm{MeOH}\right): \lambda \max : 484$ (2.86), 272 (2.79) and 1H-NMR (500 MHz, MeOD) $\delta 6.18(1 \mathrm{H}, d, J=2.0 \mathrm{~Hz}, \mathrm{H}-$ 6), $6.39(1 \mathrm{H}, d, J=2.0 \mathrm{~Hz}, \mathrm{H}-8), 6.88(1 \mathrm{H}, d, J=8.3 \mathrm{~Hz}, \mathrm{H}-$ 
$\left.5^{\prime}\right), 7.62\left(1 \mathrm{H}, d d, J=8.3 ; 2.1 \mathrm{~Hz}, \mathrm{H}-6^{\prime}\right), 7.74(1 \mathrm{H}, d, J$ $=2.1 \mathrm{~Hz}, \mathrm{H}-2^{\prime}$, ESI-MS: $m / z 300.9$ [M-H]-, 602.6 [2 M-H] [34].

\section{Ism-4}

White, waxy powder, IR ( $\left.\mathrm{KBr}, \mathrm{Cm}^{-1}\right), 3373.6,2940.7,2867.9$, 1641.6, 1457.3, 1381.6, 1038.7, 881.6. UV $\lambda \mathrm{CHCl}_{3} \max \mathrm{nm}$ : 220. 1H-NMR $(500 \mathrm{MHz}, \mathrm{CDCl} 3) \delta(\mathrm{ppm})=0.74(1 \mathrm{H}, s, \mathrm{H}-$ 18), $0.87(1 \mathrm{H}, d, J=6.9 \mathrm{~Hz}, \mathrm{H}-27), 0.88(1 \mathrm{H}, d, J=6.9 \mathrm{~Hz}$, $\mathrm{H}-26), 0.89(1 \mathrm{H}, t, J=7.4 \mathrm{~Hz}, \mathrm{H}-29), 0.93(1 \mathrm{H}, d, J=6.5 \mathrm{~Hz}$, $\mathrm{H}-21), 0.97(1 \mathrm{H}, m, \mathrm{H}-24), 0.98(1 \mathrm{H}, m, \mathrm{H}-9), 1.04(1 \mathrm{H}, m$, $\mathrm{H}-14), 1.06$ (1H, $s, \mathrm{H}-19), 1.07(1 \mathrm{H}, m, \mathrm{H}-22 \mathrm{~b}), 1.11(1 \mathrm{H}$, $t m, J=11.2 \mathrm{~Hz}, \mathrm{H}-15 \mathrm{~b}), 1.13(1 \mathrm{H}, m, \mathrm{H}-1 \mathrm{~b}), 1.16(1 \mathrm{H}, t, J=$ $10.0 \mathrm{~Hz}, \mathrm{H}-17), 1.21$ (1H, $m, \mathrm{H}-23), 1.21$ (1H, $m, \mathrm{H}-12 \mathrm{~b})$, $1.30(1 \mathrm{H}, m, \mathrm{H}-16 \mathrm{~b}), 1.31(1 \mathrm{H}, m, \mathrm{H}-28), 1.36(1 \mathrm{H}, m, \mathrm{H}-$ 22a), 1.40 (1H, $m, \mathrm{H}-20), 1.50(1 \mathrm{H}, q d, J=10.8$; $4.6 \mathrm{~Hz}, \mathrm{H}-$ 11b), 1.50 (1H, m, H-7), 1.55 (1H, $m, \mathrm{H}-11 \mathrm{a}), 1.56(1 \mathrm{H}, m$, $\mathrm{H}-2 \mathrm{~b}), 1.63(1 \mathrm{H}, m, \mathrm{H}-15 \mathrm{a}), 1.71(1 \mathrm{H}, m, \mathrm{H}-25), 1.88(1 \mathrm{H}$, $m, \mathrm{H}-2 \mathrm{a}), 1.89$ (1H, m, H-16a), 1.90 (1H, $m, \mathrm{H}-1 \mathrm{a}), 2.03(1 \mathrm{H}$, $t d, J=12.1 ; 2.4 \mathrm{~Hz}, \mathrm{H}-8), 2.06(1 \mathrm{H}, d t, J=12.8 ; 3.6 \mathrm{~Hz}, \mathrm{H}-$ 12a), $2.30(1 \mathrm{H}, t d, J=11.0 ; 2.0 \mathrm{~Hz}, \mathrm{H}-4 \mathrm{~b}), 2.34(1 \mathrm{H}$, $d d d, J=13.0 ; 5.0 ; 2.0 \mathrm{~Hz}, \mathrm{H}-4 \mathrm{a}), 3.58(1 \mathrm{H}, t t, J=11.3$; $5.3 \mathrm{~Hz}, \mathrm{H}-3), 5.40(1 \mathrm{H}, d d, J=5.2 ; 2.3 \mathrm{~Hz}, \mathrm{H}-6)$; ESIMS: $m / z: 437[\mathrm{M}+\mathrm{Na}]+[35]$.
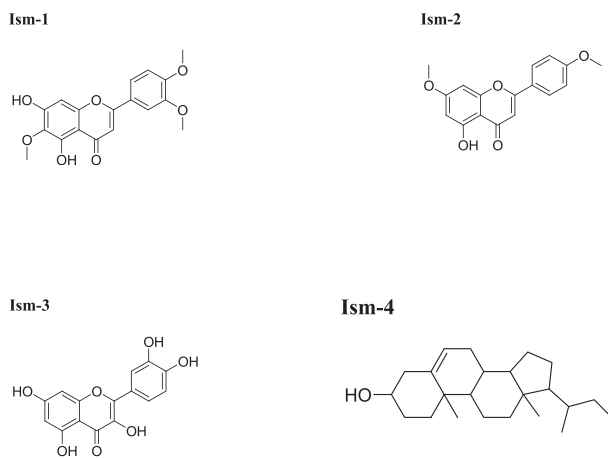

Ism-4

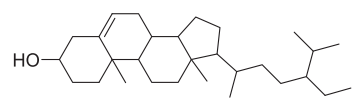

The crude methanolic extract and sub-fractions in test doses of 500,1000, 1500 and $2000 \mathrm{mg} / \mathrm{kg}$ body weight showed no adverse effects on the behavioral responses in the tested mice following 14 days observation. No mortality or weight change observed. Therefore, a highest dose of $300 \mathrm{mg} / \mathrm{kg}$ given to mice in this study was considered to be safe.

In performing the acetic acid induced writhing test for the determination of antinociceptive effect, the samples showed a significant analgesic effect. The crude methanolic extract, chloroform and ethyl acetate fraction showed a dose dependent response and significantly inhibited the acetic acid induced writhings with a maximum value of $62.64 \%(P<0.01, n=6), 71.88 \%$

$(P<0.001, n=6)$ and $66.93 \%(P<0.001, n=6)$, respectively as shown in Table 1 . Whereas, the residual aqueous fraction showed no significant activity (data not shown). All the results were compared against standard (diclofenac sodium, $50 \mathrm{mg} / \mathrm{kg}$ ) with $84.96 \%$ response.

After the administration of the crude extract and its sub-fractions to the animals treated with formalin, it showed a dose dependent response and significantly inhibited both the phases with $37.93 \%\left({ }^{* *} P<0.01, n=6\right)$, 51.34\% $\left({ }^{* * * *} P<0.001, n=6\right)$ and $45.33\left({ }^{* * *} P<0.01, n=6\right)$ in the first phase and $56.87 \%\left({ }^{* * a t} P<0.001, n=6\right), 73.54 \%$ $\left({ }^{* * * *} P<0.001, n=6\right)$ and $66.63 \%\left({ }^{* * *} P<0.01, n=6\right)$ of crude methanolic extract $(300 \mathrm{mg} / \mathrm{kg})$, chloroform and ethyl acetate fraction $(200 \mathrm{mg} / \mathrm{kg})$ respectively, for the second phase. While the aqueous fraction showed no any prominent response (data not shown).

Animals treated with morphine $(5.0 \mathrm{mg})$ significantly inhibited both the phases with $86.86 \%\left({ }^{* * *} P<0.001, n=6\right)$ and $96.11 \%$ ( $\left.{ }^{*} P<0.001, n=6\right)$ for first phase and second phase respectively as shown in Table 2. A reversal of inhibitory potential was observed in animals pre-treated with naloxone.

The results show that naloxone caused a prominent reversal effect of the analgesic potential of morphine in both the phases. Indomethacin $(10 \mathrm{mg} / \mathrm{kg})$ mildly inhibited the first phase with $20.38 \%\left({ }^{* * *} P<0.001, n=6\right)$ and significantly inhibited the second phase with $74.08 \%$ $\left({ }^{* * * *} P<0.001, n=6\right)$.

The samples (crude methanolic extract $300 \mathrm{mg} / \mathrm{kg}$, chloroform $200 \mathrm{mg} / \mathrm{kg}$ and ethyl acetate fraction $200 \mathrm{mg} / \mathrm{kg}$ ) when tested for its effectiveness in tail flick model, significantly increased the latency time to 66.54\% ( $\left.{ }^{* *} P<0.01, n=6\right), 82.94 \%\left({ }^{* *} P<0.01, n=6\right)$ and $70.53 \%\left({ }^{* * *} P<0.001, n=6\right)$ respectively at $60 \mathrm{~min}$ at which morphine (opioid analgesic, centrally acting), showed $85.07 \%\left({ }^{* * * *} P<0.001, n=6\right)$ activity resembling more to that of the chloroform fraction. Naloxone

Table 1 Acetic acid induced analgesic activity of test samples of Artemisia macrocephala

\begin{tabular}{lll}
\hline Treatment/dose & Number of writhings & \% inhibition \\
\hline Control (2 \% Tween 80) & $67.59 \pm 1.02$ & - \\
Crd 150 mg $300 \mathrm{mg}$ & $31.63 \pm 1.25^{* *}$ & 53.20 \\
& $25.25 \pm 1.05^{* *}$ & 62.64 \\
Chf 100 mg $200 \mathrm{mg}$ & $27.25 \pm 1.20^{* *}$ & 59.68 \\
& $19.00 \pm 1.35^{* * *}$ & 71.88 \\
EtOA 100 mg $200 \mathrm{mg}$ & $28.45 \pm 1.15^{* *}$ & 57.90 \\
& $22.35 \pm 1.20^{* *}$ & 66.93 \\
Diclofenac sodium (50 mg) & $10.16 \pm 0.70^{* * *}$ & 84.96
\end{tabular}

All the values were expressed as mean \pm SEM $(n=6) .{ }^{* *} P<0.01,{ }^{* * *} P<0.001$ when compared to control group

Key: Crd crude methanolic extract, chf chloroform fraction, EtOA ethyl acetate fraction 
Table 2 To show effects of Artemisia macrocephala on formalin-induced paw-licking response

\begin{tabular}{|c|c|c|c|c|c|}
\hline \multirow{2}{*}{\multicolumn{2}{|c|}{ Treatment/dose }} & \multirow{2}{*}{$\begin{array}{l}\text { Licking } \\
\text { 1st phase }\end{array}$} & \multirow{2}{*}{$\begin{array}{l}\text { Time (sec) } \\
\text { 2nd phase }\end{array}$} & \multicolumn{2}{|c|}{ Inhibition (\%) } \\
\hline & & & & 1st phase & 2nd phase \\
\hline \multicolumn{2}{|c|}{ Control (2 \% Tween 80) } & $50.03 \pm 1.63$ & $72.00 \pm 1.30$ & - & \\
\hline \multirow[t]{2}{*}{ Crd } & 150 mg & $34.22 \pm 1.12^{* *}$ & $37.25 \pm 1.619^{* *}$ & 31.60 & 48.26 \\
\hline & 300 mg & $31.05 \pm 1.125^{* *}$ & $31.05 \pm 1.668^{* * *}$ & 37.93 & 56.87 \\
\hline \multirow[t]{2}{*}{ Chf } & 100 mg & $28.25 \pm 1.65^{* *}$ & $30.50 \pm 1.425^{* *}$ & 43.53 & 57.63 \\
\hline & 200 mg & $24.34 \pm 1.411^{* * *}$ & $19.05 \pm 1.039^{* * *}$ & 51.34 & 73.54 \\
\hline \multirow[t]{2}{*}{ EtOA } & 100 mg & $28.96 \pm 1.55^{* *}$ & $30.95 \pm 1.441^{* * *}$ & 42.11 & 57.01 \\
\hline & 200 mg & $27.35 \pm 1.05^{* *}$ & $24.02 \pm 0.95^{* *}$ & 45.33 & 66.63 \\
\hline \multicolumn{2}{|c|}{ Indomethacin (10 mg) } & $39.83 \pm 1.55^{* *}$ & $18.66 \pm 1.542^{* * *}$ & 20.38 & 74.08 \\
\hline \multicolumn{2}{|c|}{ Morphine (5 mg) } & $6.41 \pm 1.165^{* * *}$ & $2.83 \pm 1.260^{* * *}$ & 86.86 & 96.11 \\
\hline \multirow[t]{2}{*}{$N+C r d$} & 150 mg & $47.15 \pm 1.75$ & $63.60 \pm 1.542$ & 5.75 & 11.66 \\
\hline & 300 mg & $47.70 \pm 1.50$ & $64.50 \pm 1.428$ & 4.65 & 10.41 \\
\hline \multirow[t]{2}{*}{$N+C h f$} & $100 \mathrm{mg}$ & $47.80 \pm 1.25$ & $65.35 \pm 1.30$ & 4.45 & 9.30 \\
\hline & 200 mg & $48.05 \pm 1.33$ & $66.65 \pm 1.45$ & 3.95 & 7.43 \\
\hline \multirow[t]{2}{*}{$\mathrm{N}+\mathrm{EtOA}$} & 100 mg & $47.75 \pm 1.23$ & $64.85 \pm 1.40$ & 4.55 & 9.93 \\
\hline & $200 \mathrm{mg}$ & $47.95 \pm 1.25$ & $65.95 \pm 1.416$ & 4.15 & 8.40 \\
\hline \multicolumn{2}{|c|}{$\mathrm{N}+$ Indomethacin (10 mg) } & $44.00 \pm 1.84^{* *}$ & $25.00 \pm 1.539^{* * *}$ & 12.05 & 65.27 \\
\hline \multicolumn{2}{|c|}{$\mathrm{N}+$ Morphine (5 mg) } & $47.66 \pm 1.52$ & $71.83 \pm 1.142$ & 2.39 & 1.37 \\
\hline
\end{tabular}

All the values were expressed as mean \pm SEM. ${ }^{*} P<0.05$, ${ }^{* *} P<0.01$ and ${ }^{* * *} P<0.001$ whencompared to control group (one way ANOVA followed by Dunnett's: compare all vscontrol test)

Key: $C r d$ crude methanolic extract, chf chloroform fraction, EtOA ethyl acetate fraction, $N$ naloxone $2 \mathrm{mg}$

treated animals significantly reduced the analgesic potentials of morphine and the test samples (Table 3).

\section{Discussion}

There are many natural products that are used in traditional medicines in various countries. Alternative system of medicine for various ailments is receiving much more attention. Many plants produce significant effect(s) like synthetic drug(s) [36]. Therefore, natural products with little side effects are compulsory to take place of chemical therapeutics [37]. Data from the literature showed that some species of the genera Artemisia possess analgesic activity and these pharmacological effects have been attributed mainly to flavonoids, alkaloids, sesquiterpene lactones and essential oils [38].

The main focus of our work is to confirm on scientific basis that $A$. macrocephala possesses antinociceptive activity. This conclusion is strengthened by three different methods used for the evaluation of antinociceptive activity. The results obtained from this study showed the presence of antinociceptive potentials of A. macrocephala in all animal models used. Acetic acid induced abdominal constriction is a quite sensitive practice that enables the detection of peripheral antinociceptive activity [9]. This test causes localized inflammation in mice due to biosynthesis of prostaglandins and leukotriens through cyclooxygenase and lipooxygenase pathway [39]. This model is based on several nociceptive mechanisms, like sympathetic system (biogenic amines release), cyclooxygenases and their metabolites [40] and opioid mechanisms [41]. Therefore, the formalin and tail immersion tests were used to find out if the plant possesses any central analgesic potential.

The formalin test is considered a valid model for clinical pain [42] and in this model; the crude extract and sub-fractions effectively inhibited the licking response in both early and late phases, in a manner more similar to that of morphine. An opioid antagonist, naloxone, greatly reversed the analgesic effect of the crude extract and sub-fractions indicating that opioid receptors are involved in the activity. However, complete antagonism was not observed, therefore, it may be concluded that the effect was due to flavonoids [43], as the plant tested positive for the presence of flavonoids [25].

In tail flick test the crude extract and sub-fractions again showed morphine like response indicating that the crude extract and sub-fractions have spinal effect. NSAIDs (Non-steroidal anti-inflammatory drugs) act by decreasing the sensitivity of pain receptors which is caused by prostaglandins [44]. Though the exact mechanism is not known, the observed activity may be due to morphine like effect of the samples. A lot of substances 
Table 3 To show analgesic activity of Artemisia macrocephala (tail flick method) and standard

\begin{tabular}{|c|c|c|c|c|c|c|}
\hline \multirow[t]{2}{*}{ Treatment/dose } & \multicolumn{6}{|c|}{ Time in sec (tail flick)/response (\%) } \\
\hline & $15 \min$ & $30 \mathrm{~min}$ & $45 \mathrm{~min}$ & $60 \mathrm{~min}$ & $75 \mathrm{~min}$ & $90 \mathrm{~min}$ \\
\hline Control (2 \% Tween 80) & $0.79 \pm 0.035$ & $0.89 \pm 0.025$ & $0.97 \pm 0.027$ & $0.94 \pm 0.036$ & $0.87 \pm 0.027$ & $0.93 \pm 0.045$ \\
\hline \multirow[t]{2}{*}{ Crd 150 mg 300 mg } & $\begin{array}{l}0.97 \pm 0.130 \\
(18.55 \%)\end{array}$ & $\begin{array}{l}1.24 \pm 0.124^{*} \\
(28.22 \%)\end{array}$ & $\begin{array}{l}1.69 \pm 0.139 \\
(42.60 \%)\end{array}$ & $\begin{array}{l}2.10 \pm 0.122^{* *} \\
(55.23 \%)\end{array}$ & $\begin{array}{l}2.34 \pm 0.134^{* *} \\
(62.82 \%)\end{array}$ & $\begin{array}{l}2.05 \pm 0.124^{* *} \\
(54.63 \%)\end{array}$ \\
\hline & $\begin{array}{l}1.09 \pm 0.130^{*} \\
(27.52 \%)\end{array}$ & $\begin{array}{l}1.40 \pm 0.121^{*} \\
(36.42 \%)\end{array}$ & $\begin{array}{l}1.92 \pm 0.129^{* *} \\
(49.47 \%)\end{array}$ & $\begin{array}{l}2.77 \pm 0.130^{* *} \\
(66.06 \%)\end{array}$ & $\begin{array}{l}3.18 \pm 0.165^{* * *} \\
(72.64 \%)\end{array}$ & $\begin{array}{l}3.03 \pm 0.140^{* * *} \\
(69.30 \%)\end{array}$ \\
\hline \multirow[t]{2}{*}{ Chf 100 mg 200 mg } & $\begin{array}{l}1.10 \pm 0.995^{*} \\
(28.18 \%)\end{array}$ & $\begin{array}{l}1.35 \pm 0.399^{*} \\
(34.07 \%)\end{array}$ & $\begin{array}{l}1.98 \pm 0.236^{* *} \\
(51.01 \%)\end{array}$ & $\begin{array}{l}3.37 \pm 0.220^{* *} \\
(72.10 \%)\end{array}$ & $\begin{array}{l}3.75 \pm 0.213^{* * *} \\
(76.80 \%)\end{array}$ & $\begin{array}{l}3.31 \pm 0.237^{* * *} \\
(71.90 \%)\end{array}$ \\
\hline & $\begin{array}{l}1.16 \pm 0.029^{*} \\
(31.89 \%)\end{array}$ & $\begin{array}{l}1.41 \pm 0.021^{*} \\
(36.87 \%)\end{array}$ & $\begin{array}{l}2.10 \pm 0.042^{* *} \\
(53.80 \%)\end{array}$ & $\begin{array}{l}5.29 \pm 0.060^{* *} \\
(82.23 \%)\end{array}$ & $\begin{array}{l}4.33 \pm 0.041^{* * *} \\
(79.90 \%)\end{array}$ & $\begin{array}{l}4.47 \pm 0.057^{* * *} \\
(79.19 \%)\end{array}$ \\
\hline \multirow[t]{2}{*}{ EtOA 100 mg 200 mg } & $\begin{array}{l}1.04 \pm 0.214^{*} \\
(24.03 \%)\end{array}$ & $\begin{array}{l}1.29 \pm 0.241^{*} \\
(31.00 \%)\end{array}$ & $\begin{array}{l}1.87 \pm 0.361^{* *} \\
(48.12 \%)\end{array}$ & $\begin{array}{l}3.10 \pm 0.421^{* *} \\
(69.67 \%)\end{array}$ & $\begin{array}{l}3.38 \pm 0.302^{* *} \\
(74.26 \%)\end{array}$ & $\begin{array}{l}2.76 \pm 0.280^{* * *} \\
(66.30 \%)\end{array}$ \\
\hline & $\begin{array}{l}1.10 \pm 0.201^{*} \\
(28.18 \%)\end{array}$ & $\begin{array}{l}1.33 \pm 0.202^{*} \\
(33.08 \%)\end{array}$ & $\begin{array}{l}1.91 \pm 0.350^{* *} \\
(49.21 \%)\end{array}$ & $\begin{array}{l}3.19 \pm 0.435^{* *} \\
(70.53 \%)\end{array}$ & $\begin{array}{l}3.30 \pm 0.313^{* * *} \\
(73.63 \%)\end{array}$ & $\begin{array}{l}2.79 \pm 0.291^{* * *} \\
(66.66 \%)\end{array}$ \\
\hline Standard (Morphine 5 mg) & $\begin{array}{l}1.52 \pm 0.024 \\
(48.02 \%)\end{array}$ & $\begin{array}{l}2.03 \pm 0.066 \\
(56.15 \%)\end{array}$ & $\begin{array}{l}3.89 \pm 0.038 \\
(75.06 \%)\end{array}$ & $\begin{array}{l}6.30 \pm 0.054 \\
(85.07 \%)\end{array}$ & $\begin{array}{l}4.40 \pm 0.050 \\
(80.22 \%)\end{array}$ & $\begin{array}{l}4.30 \pm 0.074 \\
(78.37 \%)\end{array}$ \\
\hline \multirow[t]{2}{*}{$\mathrm{N}+\mathrm{Crd} 150 \mathrm{mg} 300 \mathrm{mg}$} & $0.79 \pm 0.108$ & $0.95 \pm 0.044$ & $0.99 \pm 0.045$ & $0.99 \pm 0.064$ & $0.95 \pm 0.026$ & $0.81 \pm 0.042$ \\
\hline & $0.84 \pm 0.046$ & $0.98 \pm 0.031$ & $1.14 \pm 0.047$ & $0.99 \pm 0.035$ & $0.96 \pm 0.051$ & $0.92 \pm 0.034$ \\
\hline \multirow[t]{2}{*}{$\mathrm{N}+$ Chf 100 mg 200 mg } & $0.93 \pm 0.048$ & $0.92 \pm 0.036$ & $1.10 \pm 0.031$ & $1.10 \pm 0.047$ & $0.90 \pm 0.038$ & $0.93 \pm 0.061$ \\
\hline & $0.87 \pm 0.037$ & $0.91 \pm 0.065$ & $1.50 \pm 0.049$ & $0.99 \pm 0.038$ & $0.89 \pm 0.029$ & $0.95 \pm 0.044$ \\
\hline \multirow[t]{2}{*}{$\mathrm{N}+\mathrm{EtOA} 100$ mg 200 mg } & $0.89 \pm 0.033$ & $0.93 \pm 0.051$ & $1.20 \pm 0.051$ & $1.11 \pm 0.034$ & $0.91 \pm 0.061$ & $0.90 \pm 0.056$ \\
\hline & $0.85 \pm 0.037$ & $0.90 \pm 0.065$ & $0.99 \pm 0.049$ & $1.12 \pm 0.038$ & $0.91 \pm 0.029$ & $0.99 \pm 0.044$ \\
\hline $\begin{array}{l}\text { Morphine }(5 \mathrm{mg})+\text { Naloxone } \\
(2 \mathrm{mg})\end{array}$ & $0.77 \pm 0.022$ & $0.87 \pm 0.036$ & $0.94 \pm 0.040$ & $0.91 \pm 0.034$ & $0.91 \pm 0.030$ & $0.91 \pm 0.042$ \\
\hline
\end{tabular}

All the values were expressed as mean \pm SEM. ${ }^{*} P<0.05,{ }^{*} P<0.01$ and ${ }^{* * *} P<0.001$ when compared to control group (one way ANOVA followed by Dunnett's: compared all vs control test)

Key: $\mathrm{Crd}$ crude methanolic extract, chf chloroform fraction, EtOA ethyl acetate fraction, $\mathrm{N}$ naloxone $2 \mathrm{mg}$

with spinal analgesic activity are present in literature among which the most familiar one is morphine [45]. In a similar way, we tried to find out on scientific basis the antinociceptive potentials of $A$. macrocephala, which showed morphine like antinociceptive activity, which increases the list of pharmacological activities already mentioned for $A$. macrocephala. This discovery encourages our previous work of relaxant activity of the crude extract and essential oil of A. macrocephala [25]. Moreover, flavonoids are polyphenolic compounds and are plant's secondary metabolites. They are becoming the focus of medical research since they possess useful properties like antiviral [46], anti-inflammatory, antitumour, antiallergic, antimicrobial, antioxidant, cytotoxic, enzyme inhibition, oestrogenic [47, 48], vasodilating [49], antipyretic and analgesic activities [50]. Based upon the above findings (Tables 1, 2 and 3), and the pharmacological potentials of flavonoids, the pharmacologically rich chloroform and ethyl acetate fractions were subjected to column chromatography for the isolation of active bio molecules. These bio-molecules (Ism-1, Ism-2, Ism-3 and Ism-4) are currently under scientific investigations for possible analgesic activity and its mechanistic approach to determine the involvement of various receptors apart from opioid receptor that play important role in nociception. This ongoing research will standardize the specie for bio-guided isolation of targeted pharmacologically active moieties.

\section{Conclusion}

The results show that $A$. macrocephala is rich with bioactive compounds producing analgesic effect. A. macrocephala can be further investigated for the isolation and structure elucidation of the bioactive compounds responsible for analgesic activity and to explore its possible mechanism of action.

\section{Additional file}

Additional file 1: Spectra analysis. (DOC $6349 \mathrm{~kb}$ )

\section{Acknowledgments}

The authors are thankful to University of Malakand Chakdara Dir Lower KPK, and International Center for Chemical and Biological Sciences (ICCBS, HEJ), Karachi, Pakistan for providing the facilities.

Funding source

No fund was provided by any funding agency for this study. 


\section{Authors' contributions}

MS helped in supervision. IS (PhD Scholar) carried out research work. NA helped in supervision and pharmacological screenings. SWA helped in carrying out the activities and writing manuscript. All authors read and approved the final version of manuscript.

\section{Competing interests}

The authors declare that they have no competing interests.

\section{Consent}

Not relevant.

\section{Ethics}

Standard experimental protocols were followed as per the guidelines of ethical committee of Department of Pharmacy (No: E-AM-01-2009), University of Malakand as per Bye Laws 2008 of the University of Malakand (Scientific Procedures Issue-l).

\section{Author details}

'Department of Pharmacy, University of Malakand, Chakdara Dir Lower, Khyber Pakhtunkhwa (KPK), Pakistan. ${ }^{2}$ Institute of Basic Medical Sciences, Khyber Medical University Peshawar, Peshawar, KPK, Pakistan.

\section{Received: 30 July 2015 Accepted: 13 May 2016 \\ Published online: 26 May 2016}

\section{References}

1. Pires JM, Fulvio RM, Negri G, Duarte Almeida JM, Elisaldo AC. Antinociceptive peripheral effect of Achillea millefolium L. and Artemisia vulgaris L. Both plants known popularly by brand names of analgesic drugs. Phytother Res. 2009;23: 212-9.

2. Fiorucci S, Antonelli E, Morelli A. Mechanism of nonsteroidal antiinflammatory drug gastropathy. Dig Liver Dis. 2001;33:35-43.

3. Sam R. Integrated pain management: using omega 3 fatty acids in a naturopathic model. Tech Reg Anesth Pain Manag. 2008;12:105-8.

4. Zulfiker AHM, Rahman MM, Hossain MK, Hamid K, Mazumder MEH, Rana MS. In vivo analgesic activity of ethanolic extracts of two medicinal plants - Scoparia dulcis L. and Ficus racemosa Linn. Biology and Medicine. 2010;2:42-8.

5. Grkovic T, Pouwer RH, Vial M-L, Gambini L, Noel A, Hooper JNA, Wood SA, Mellick GD, Quinn RJ. NMR fingerprints of the drug-like natural-product space identify iotrochotazinea: a chemical probe to study Parkinson's disease. Angew Chem Int Ed. 2014;53:6070-4.

6. Calixto JB, Beirith A, Ferreira J, Santos ARS, Filho VC, Yunes RA. Naturally occurring antinociceptive substances from plants. Phytother Res. 2000;14:401-18.

7. Gilani AH, Attaur R. Trends in ethnopharmacology. J Ethnopharmacol. 2005; 100:43-9.

8. Soulange JG, Magan N, Fakim AG, Gauvin A, Smadja J, Kodja H. Chemical composition and in vitro antimicrobial activities of the essential oils from endemic Psiadia species growing in Mauritius. Biol Pharm Bull. 2004;11: 1814-8.

9. Takahashi HT, Novello CR, Nakamura TU, Filho BPD, Mello JCP, Nakamura CV. Thiophene derivatives with antileishmanial activity isolated from aerial parts of Porophyllum ruderale (Jacq.) Cass. Molecules. 2011;16:3469-78.

10. Alzoreky NS, Nakahara K. Antibacterial activity of extracts from some edible plants commonly consumed in Asia. IntJ Food Microbiol. 2003; 80:223-30.

11. Qnais E, Raad D, Bseiso Y. Analgesic and anti-inflammatory effects of an extract and flavonoids from Artemisia herba-alba and their mechanisms of action. Neurophysiology. 2014;46:238-46.

12. Mino J, Moscatelli V, Hnatyszyn O, Gorzalczany S, Acevedo C, Ferraro G. Antinociceptive and antiinflammatory activities of Artemisia copa extracts. Pharmacol Res. 2004;50:59-63.

13. Zeraati F, Ashari FE, Araghchian M, Emam AH, Rad MV, Seif S, Razaghi K. Evaluation of topical antinociceptive effect of Artemisia absinthium extract in mice and possible mechanisms. Afr J Pharm Pharmacol. 2014;8:492-6.

14. Eidi A, Oryan S, Zaringhalam J, Rad M. Antinociceptive and anti-inflammatory effects of the aerial parts of Artemisia dracunculus in mice. Pharm boil. 2015;1:1-6.

15. Valless J, Garcia S, Hidalgo O, Martín J, Pellicer J, Sanz Met Garnatje T. Biology, genome evolution, biotechnological issues and research including applied perspectives in Artemisia (Asteraceae). Adv Botan Res. 2011;60:349-419.
16. Filho AW, Filho VC, Olinger L, de Souza MM. Quercetin: further investigation of its antinociceptive properties and mechanisms of action. Arch Pharm Res. 2008;31:713-21.

17. Block LC, Santos ARS, de Souza MM, Scheidt C, Yunes RA, Alves Santos M, Monache FD, Filho VC. Chemical and pharmacological examination of antinociceptive constituents of Wedelia paludosa. J Ethnopharmacol. 1998; 61:85-9.

18. Gupta A, Saifi AQ, Modi NT, Rao SS, Mishra N. Antiinflammatory activity of some active principles of Lawsonia inermis leaves. Indian J Pharmacol. 1986;18:113-4.

19. Kotanidou A, Xagorari A, Bagli E, Kitsanta P, Fotsis T, Papapetropoulos A, Roussos C. Luteolin reduces lipopolysaccharide-induced lethal toxicity and expression of pro-inflammatory molecules in mice. Am J Respir Crit Care Med. 2002:165:818-23.

20. Kim JH, Kim HK, Kwon Kang S, Kim EU, Kang SK, Sung ND, Kwon BM. New sesquiterpene-monoterpene lactone, artemisolide, isolated from Artemisia argyi. Tetrahedron Lett. 2002;43:6205-8.

21. Lu YY, Chen TS, Qu JL, Pan WL, Sun L, Wei XB. Dihydroartemisinin (DHA) induces caspase-3-dependent apoptosis in human lung adenocarcinoma ASTC-a-1 cells. J Biomed Sci. 2009;16:16-31.

22. Choi EJ, Lee S, Chae JR, Lee HS, Jun CD, Kim SH. Eupatilin inhibits lipopolysaccharide-induced expression of inflammatory mediators in macrophages. Life Sci. 2011;20:1121-6.

23. Yang Z, Ding J, Yang C, Gao Y, Li X, Chen X, Peng Y, Fang J, Xiao S. Immunomodulatory and anti-inflammatory properties of Artesunate in experimental colitis. Curr Med Chem. 2012;19:4541-45451.

24. Cantarelli MA, Pellerano RG, Vitto LAD, Marchevskyb EJ, Caminaa JM. Characterization of two South American food and medicinal plants by chemometric methods based on their multielemental composition. Phytochem Analysis. 2010;21:550-5.

25. Ali N, Shah I, Shah SWS, Ahmed G, Shoaib M, Junaid M, Ali W, Ahmed Z Antioxidant and relaxant activity of fractions of crude methanol extract and essential oil of Artemisia macrocephala Jacquem. BMC Complem Altern Med. 2013;13:1-8.

26. Cheng SS, Huang CG, Chen YJ, Yu JJ, Chen WJ, Chang ST. Chemical compositions and larvicidal activities of leaf essential oils from two eucalyptus species. Bioresource Technol. 2009;100:452-6.

27. Shoaib M, Shah I, Ali N, Shah SWA. In vitro acetylcholinesterase and butyrylcholinesterase inhibitory potentials of essential oil of Artemisia macrocephala. Bangladesh J Pharmacol. 2015;10:87-91.

28. Lorke D. A new approach to practical acute toxicity testing. Arch Toxicol. 1983;54(4):275-87.

29. Koster R, Anderson M, De Beer EJ. Acetic acid for analgesic screening. Fed Proc. 1959:18:412-6.

30. Pandurangan SB, Paul AS, Savarimuthu I, Ali AA. Antinociceptive, immunomodulatory and antipyretic activity of nymphayol isolated from Nymphaea stellata (Willd.) flowers. Biomol Ther. 2013;21:391-7.

31. Moniruzzaman M, Imam MZ. Evaluation of antinociceptive effect of methanolicextract of leaves of Crataeva nurvala Buch.-Ham. BMC Complem Altern Med. 2014;14:354-60.

32. Kang YJ, Jung UJ, Lee MK, Kim HJ, Jeon SM, Park YB, Chung HG, Baek NI, Lee KT, Jeong TS, Choi MS. Eupatilin, isolated from Artemisia princeps Pampanini, enhances hepatic glucose metabolism and pancreatic beta-cell function in type 2 diabetic mice. Diabetes res clin pr. 2008;82:25-32.

33. Ahmad VU, Rahman AU. Hand book of natural product data, Penta cyclic triterpenoids, vol. 2. Amsterdam: Elsvier; 1994. p. 1064.

34. Zuhal G, Omur LD. Flavonol Glycosides from Asperula arvensis L. Turk J Chem. 2005:29:163-9.

35. Anjoo K, Ajay KS. Isolation of stigmasterol and $\beta$ sitosterol from petroleum ether extract of aerial parts of Ageratum conyzoides (asteraceae). Int J Pharm Pharm Sci. 2011;3:94-6.

36. Aisha A, Raja AS, Adeel M, Moin D. Chemical composition and in vitro antioxidant and antitumor activities of Eucalyptus camaldulensis Dehn. leaves. Ind Crop Prod. 2015;74:241-8.

37. Verpoorte R. Exploration of nature's chemodiversity: the role of secondary metabolites as leads in drug development. Drug Discov Today. 1999;3: 232-8.

38. Heinrich M, Ankli A, Frei B, Weimann C, Sticher O. Medicinal plants in Mexico: healers' consensus and cultural importance. Pergamon. 1998:47:1859-71.

39. Muhammad AK, Aziz AR, Laizuman N, Md Bl, Khurshaid AAHM. In vivo analgesic and CNS depressant activities of antioxidative stem bark fraction of Morus alba L. Dhaka Univ J Pharm Sci. 2014;13:225-7. 
40. Duarte IDG, Nakamura M, Ferreira SH. Participation of the sympathetic system in acetic acid-induced writhing in mice. Braz J Med Biol Res. 1988;21:341-3.

41. Collier HOJ, Dinneen JC, Johnson CA, Schneider C. The abdominal constriction response and its suppression by analgesic drugs in the mouse. $\mathrm{Br} J$ Pharmaco Chemother. 1968;32:295-310.

42. Tjølsen A, Berge OG, Hunskaar S, Rosland JH, Hole K. The formalin test: an evaluation of the method. Pain. 1992;51:5-17.

43. Valiollah H, Alireza G, Hadi J. Black cumin seed essential oil, as a potent analgesic and antiinflammatory drug. Phytother Res. 2004;18:195-9.

44. Dhara AK, Suba V, Sen T, Pal S, Chaudhuri AKN. Preliminary studies on the anti-inflammatory and analgesic activity of the methanol fraction of the root extract of Tragia involucrata Linn. J Ethnopharmacol. 2000;72:265-8.

45. Rossi GC, Pasternak GW, Bodnar RJ. Synergistic brainstem interactions for morphine analgesia. Brain Res. 1993;62:171-80.

46. Orhan DD, Ozcelik B, Ozgen S, Ergun F. Antibacterial, antifungal, and antivira activities of some flavonoids. Microbiol Res. 2010;165:496-504.

47. Nijveldt RJ, Nood EV, Hoorn DEC, Boelens PG, Norren K, Leeuwen PAM. Flavonoids: a review of probable mechanisms of action and potential applications. Am J Clin Nut. 2001;74:418-25.

48. Cushnie TPT, Lamb AT. Antimicrobial activity of flavonoids. Int J Antimicro Ag. 2005;26:343-56.

49. Ghayur MN, Khan H, Gilani AH. Antispasmodic, bronchodilator and vasodilator activities of (+)-catechin, a naturally occurring flavonoid. Arch Pharm Res. 2007; 30:970-5.

50. Bamidele VO, Stephen OO, Kemi D, Bolatito AO, Elizabeth AA, Ayodele OS. Analgesic, anti-inflammatory and antipyretic activities from flavonoid fractions of Chromolaena odorata. J Med Plant Res. 2008;2:219-25.

\section{Submit your next manuscript to BioMed Central and we will help you at every step:}

- We accept pre-submission inquiries

- Our selector tool helps you to find the most relevant journal

- We provide round the clock customer support

- Convenient online submission

- Thorough peer review

- Inclusion in PubMed and all major indexing services

- Maximum visibility for your research

Submit your manuscript at www.biomedcentral.com/submit
C Biomed Central 